J. Clin. Chem. Clin. Biochem.

Vol. 24, 1986, pp. $821-829$

(C) 1986 Walter de Gruyter \& Co. Berlin - New York

\title{
Preventive Effects of Acute Inflammation on Liver Cell Necrosis and Inhibition of Heparan Sulphate Synthesis in Hepatocytes
}

\author{
By A.M. Gressner and T. Pfeiffer \\ Abteilung für Klinische Chemie und Zentrallaboratorium, Philipps-Universität, Marburg, FRG
}

(Received April 1/May 29, 1986)

Summary: The hepatocytoprotective effect of acute, turpentine-induced inflammation on experimental liver injury, caused by thioacetamide and $D$-galactosamine, respectively, was studied in relation to the synthesis of glycosaminoglycans and of heparan sulphate in hepatocytes isolated from livers of treated rats. As judged from biochemical parameters of liver cell lesion in serum (various cytosolic and mitochondrial enzymes, bile acids) the extent of liver damage caused by either noxious agent was greatly attenuated under acute inflammatory conditions. There was an inverse statistical correlation $(r=-0.63$ to $r=-0.84)$ between the functional concentration of a proteinase inhibitor protein determined with the chromogenic substrate assay for human $\alpha_{2}$-macroglobulin and the catalytic concentrations of various cell leakage enzymes in serum from liver-injured rats with turpentine-generated inflammation. The strong inhibition of heparan sulphate synthesis in hepatocytes from injured livers (synthesis rate between 0.2 and 0.4 of that in control cell incubations) is abolished in hepatocytes from livers exposed to the noxious agents but with acute inflammation. The latter condition alone caused a 1.8 fold increase in heparan sulphate synthesis of hepatocytes. Heparan sulphate was the only type of glycosaminoglycan synthesized under all conditions. The results are discussed in view of the pathogenetic potential of heparan sulphate for liver cell necrosis.

\section{Präventiver Effekt der akuten Entzündung auf die Leberzellnekrose und Hemmung der Heparansulfat-Synthese in Hepatocyten}

Zusammenfassung: Der hepatocytoprotektive Effekt der akuten, Terpentin-induzierten Entzündung wurde an zwei Modellen der experimentellen Leberschädigung, der Thioacetamid- und der D-Galactosamin-Schädigung, untersucht und in Beziehung gesetzt zu der Synthese von Glykosaminoglykanen und Heparansulfat in Hepatocyten, die aus diesen Lebern isoliert wurden. Gemessen an den biochemischen Kenngrößen der Leberzelläsion im Serum (einige zytosolische und mitochondriale Enzyme, Gallensäuren) ist das Ausmaß der mit beiden Lebergiften erzeugten Leberschädigung unter der Bedingung der akuten Entzündung stark abgeschwächt. Es ergab sich eine inverse statistische Korrelation $(r=-0,63$ bis $r=-0,84)$ zwischen der funktionellen Konzentration eines Proteinaseinhibitor-Proteins, welches bestimmt wurde mit dem chromogenen Substratasssay für humanes $\alpha_{2}$-Makroglobulin und den katalytischen Konzentrationen verschiedener Zelläsionsenzyme im Serum lebergeschädigter Ratten, die gleichzeitig eine Terpentin-erzeugte Entzündung hatten. Die starke Hemmung der Heparansulfat-Synthese in Hepatocyten von frühgeschädigten Lebern (Syntheserate zwischen 0,2 und 0,4 der der Kontrollzellinkubationen) ist aufgehoben in Hepatocyten von Lebern, die zwar der leberschädigenden Noxe exponiert waren, aber gleichzeitig eine akute Entzündung hatten. Die letżtgenannte Bedingung alleine verursachte eine 1,8fache Steigerung der Heparansulfat-Synthese in Hepatọcyten. Heparansulfat war der einzige Typ von Glykosaminoglykanen, der unter allen Bedingungen synthetisiert wurde. Die Ergebnisse werden diskutiert unter dem Aspekt der möglichen pathogenetischen Rolle des Heparansulfates für Leberzellnekrosen. 


\section{Introduction}

Human and animal liver contains, with the exception of keratan sulphate, the whole set of glycosaminoglycans and proteoglycans. The concentrations of these compounds in tissue are normally rather low being 92 to $108 \mu \mathrm{mol}$ hexosamine per $\mathrm{g}$ defatted dry weight (1) and 160 to $230 \mu \mathrm{g}$ uronic acid per g defatted dry weight (2). The most prominent hepatic proteoglycan is heparan sulphate, which resides preferentially at the liver cell surface forming an important constituent of the liver cell coat or glycocalyx (3). Although the structural details of liver cell surface heparan sulphate have been elucidated recently $(4-7)$ the knowledge on its physiological and pathobiochemical role is still scanty. In accordance with a previously established hypothesis, we propose for liver heparan sulphate a significant role in the pathogenetic sequence of liver cell injury (8). The assumption is based on the experimental observation that the synthesis of both total and liver cell surface heparan sulphate is inhibited almost instantaneously after induction of toxic liver injury by $D$-galactosamine (9) or thioacetamide (10, 11). Because of the extraordinarily high $\mathrm{Ca}^{2+}$-binding capacity of $\mathrm{N}$-sulphated (heparin-like) glycosaminoglycans (12) this type of proteoglycan is most likely responsible for the high concentration of $\mathrm{Ca}^{2+}$ at the external cell coat (13). Its function as an ion filter may hinder, together with other mechanisms, the influx of $\mathrm{Ca}^{2+}$ into the cell and, thus, might be responsible for the great intra-extracellular gradient of this divalent cation. The disruption of the ion gradient due to a highly increased intracellular $\mathrm{Ca}^{2+}$. concentration is an early and according to several reports likely causative event of liver cell necrosis $(14-20)$. The prompt loss of cell surface heparan sulphate might be, according to this hypothesis, the pathogenetic determinant for the finally lethal entry of $\mathrm{Ca}^{2+}$ into the injured cell. Consequently, livers protected from toxic injuries might exhibit, despite the application of the injurious agents, an unchanged synthesis of heparan sulphate. To prove this assumption we studied in hepatocytes from protected and non-protected livers exposed to hepatotoxic chemicals the synthesis of total glycosaminoglycans and of heparan sulphate. As a model of liver cell protection we evaluated in some details the beneficial effects of "counter irritation" on liver cell necrosis $(21,22)$. It was reported that induction of inflammation by intraperitoneal injection of $\mathrm{BaSO}_{4}$ apparently protects rats from $D$-galactosamine provoked liver injuries (23). We extended the study on thioacetamide injury, a quite differently acting hepatotoxic agent, and applied turpentine as an inflammatory agent. In addition, the degree of liver cell protection was related to the functional concentrations of some inhibitors of proteinases.

\section{Materials and Methods}

\section{Materials}

Turpentine and $D$-galactosamine- $\mathrm{HCl}$ were obtained from $\mathrm{C}$. Roth KG, Karlsruhe, FRG; collagenase (type I from Clostridium histolyticum) and calf thymus DNA were from Sigma Chem. Co., Munich, FRG; DEAE sephacel was from Pharmacia Fine Chem. Uppsala, Sweden; thioacetamide p. a. was from Merck AG, Darmstadt, FRG; sodium [ ${ }_{1}^{3 j}$ S]sulphate $(18.5-22.2$ $\mathrm{TBq} / \mathrm{mol}$ ) was from New Engl. Nuclear Corp., Boston, USA, and deoxyribonuclease (type I from bovine pancreas) was from Boehringer Mannheim GmbH, FRG. The commercial sources and specifications of all other reagents were as described elsewhere $(10,11,24)$.

\section{Treatment of rats}

Male Sprague-Dawley rats $(220-260 \mathrm{~g}$ body weight, Lippische Versuchstieranstalt, Extertal, FRG) had free access to tapwater but were deprived of food $12 \mathrm{~h}$ before isolation of hepatocytes, after subcutaneous injection of $0.5 \mathrm{ml}$ of turpentine and after initiation of liver injury either by intraperitoneal injection of thioacetamide $(100 \mathrm{mg} / \mathrm{kg}$ body weight) or $\dot{D}$-galactosamine $(500 \mathrm{mg} / \mathrm{kg}$ body weight), each freshly dissolved in saline.

\section{Isolation and incubation of hepatocytes}

Parenchymal liver cells were isolated by the method of Seglen (25) incorporating slight modifications. The rats were anaesthetized with an intraperitoneal injection of phenobarbital (Nembutal ${ }^{\circledR}, 54 \mathrm{mg} / \mathrm{kg}$ body weight) and the liver was preperfused in situ via the portal vein in a noncirculating way for $10 \mathrm{~min}$ with $\mathrm{Ca}^{2+}$-free Hank's balanced salt solution pH 7.4 at $37^{\circ} \mathrm{C}$ at a flow rate of $30 \mathrm{ml} / \mathrm{min}$ followed by recirculating perfusion ex situ for further $15 \mathrm{~min}$ with $\mathrm{Ca}^{2+}(5 \mathrm{mmol} / \mathrm{l})$, collagenase $(0.5 \mathrm{~g} / \mathrm{l})$ and deoxyribonuclease $(0.05 \mathrm{~g} / \mathrm{l})$ containing oxygenated Hank's balanced salt solution (pH 7.4 at $37^{\circ} \mathrm{C}$ ) at a flow rate of $50 \mathrm{ml} / \mathrm{min}$. Thereafter, the liver capsule was gently removed, the tissue was dissected and incubated in $100 \mathrm{ml}$ collagenasecontaining oxygenated Hank's buffer for $10 \mathrm{~min}$ at $37^{\circ} \mathrm{C}$ under constant swirling, after which the material was filtered through a double layer of sterile gauze. The initial cell suspension obtained in the filtrate was purified by differential centrifugation, first for $2 \mathrm{~min}$ at $36 \mathrm{~g}$ and second two times for $2 \mathrm{~min}$ at $17 \mathrm{~g}$, each at $4^{\circ} \mathrm{C}$. The viability of the final parenchymal cell suspension, checked by trypan blue exclusion $(2.5 \mathrm{~g} / \mathrm{l})$, was between 80 and $90 \%$, the cell recovery was between $2 \cdot 10^{8}$ and $5 \cdot 10^{8}$ cells/liver, and the contamination with non-parenchymal cells was less than $1 \%$.

Incubation of hepatocytes and determination of glycosaminoglycan synthesis

Suspensions of hepatocytes were incubated at $37^{\circ} \mathrm{C}$ up to $8 \mathrm{~h}$ in a total volume of $7.5 \mathrm{ml}$ at a density of $3.3 \times 10^{6}$ cells per $\mathrm{ml}$ in Dulbecco's modification of Eagles medium containing $1000 \mathrm{U} / 1$ penicillin and $100 \mathrm{mg} / \mathrm{l}$ streptomycin and supplemented with $L$-glutamine $(4 \mathrm{mmol} / \mathrm{l})$ and $250 \mathrm{MBq} / \mathrm{l}$ of $\left[{ }^{35}\right.$ S]sulphate. The suspension was continuously gassed with a mixture of $0.95 \mathrm{O}_{2}-0.05 \mathrm{CO}_{2}$ at a flow rate of $10 \mathrm{ml} / \mathrm{min}$ and mixed by an up-and-down cycle with a frequency of $12 \mathrm{~min}^{-1}$ (Bühler Zellkultur-Anlage, Tübingen, FRG). After incubating the cells for various times with $\left[{ }^{35} S\right]$ sulphate, aliquots of about $3 \times 10^{6}$ cells were aspirated and, after removal of a portion for the determination of DNA, centrifuged $\left(600 \mathrm{~g}, 5 \mathrm{~min}, 4^{\circ} \mathrm{C}\right)$, denatured for $5 \mathrm{~min}$ at $100^{\circ} \mathrm{C}$ and thereafter proteolysed in $5 \mathrm{ml}$ papain containing buffer $\left(\mathrm{pH}\right.$ 6.2) for $48 \mathrm{~h}$ at $57^{\circ} \mathrm{C}$ with papain as described $(10,11,26)$. The final proteolysate was cooled, centrifuged $(2400 \mathrm{~g}, 5 \mathrm{~min})$ and the supernatant was mixed for $10 \mathrm{~min}$ at $\mathrm{pH} 6.2$ with $0.5 \mathrm{ml}$ of DEAE-sephacel 
(suspended in $0.3 \mathrm{~mol} / 1 \mathrm{NaCl}, \mathrm{pH} 6.2$ ) in the presence of unlabeled glycosaminoglycans added as carrier $(10,24)$. After centrifugation $(2400 \mathrm{~g}, 5 \mathrm{~min})$ the supernatant was discarded, the DEAE-sephacel was washed four times with $4 \mathrm{ml}$ of 0.3 $\mathrm{mol} / 1$ sodium acetate, $\mathrm{pH} 6.2$ and thereafter total glycosaminoglycans were eluted with $2 \mathrm{ml}$ of $2.2 \mathrm{~mol} / 1 \mathrm{NaCl}$, of which the radioactivity was measured in a Packard Crystal liquid scintillation counter. Each incubation was performed in duplicate; cells of treated animals were always incubated alongside those of control livers.

Differentiation of total glycosaminoglycans was achieved by selective degradation with nitrous acid to obtain heparan sulphate, by enzymatic hydrolysis with chondroitin AC- (EC 4.2.2.5) and $A B C$-lyases (EC 4.2.2.4) to obtain the incorporation of label into chondroitin sulphate and dermatan sulphate, respectively, and by ion exchange chromatography on Dowex $1 \times 2\left(\mathrm{Cl}^{-}\right)$as previously described $(10,11,24,26)$.

\section{Determination of proteinase inhibitor concentration}

The concentrations of proteinase inhibitors in rat serum were determined with chromogenic substrate assays developed for human $\alpha_{2}$-macroglobulin and $\alpha_{1}$-proteinase inhibitor $\left(\alpha_{1}\right.$-antitrypsin), respectively, as described elsewhere (27) adopted to a Cobas Bio centrifugal analyser (Hoffmann La Roche, Grenzach, FRG). The analytic critera of the procedure have been reported (28).

\section{Determination of serum bile acid concentration}

Total bile acids were quantitated enzymatically (29) using a reagent test kit from Merck AG, Darmstadt, FRG. The assay was fully mechanized on a Cobas Bio centrifugal analyser; the coefficient of variation of the day-to-day imprecision was $6 \%$ $(\overline{\mathbf{x}}=15 \mu \mathrm{mol} / \mathrm{l})$.

\section{Determination of DNA}

Cells of the suspension were quantitated either by counting with a haemocytometer (Neubauer chamber) or by fluorometric determination of DNA (30) using calf thymus DNA as a standard. For the latter assay the cells were disintegrated by two cycles of freezing and thawing. The intra-series and interseries imprecision of the method are characterized by coefficients of variation of $4.2 \%$ and $7.5 \%(\overline{\mathrm{x}}=350 \mu \mathrm{g})$, respectively.

Determination of serum enzyme catalytic activity concentrations

Blood was aspirated from V. cava inf. prior to the cannulation of the portal vein for the isolation of hepatocytes. The catalytic concentrations of aspartate aminotransferase (EC 2.6.1.1); alanine aminotransferase (EC 2.6.1.2), glutamate dehydrogenase (EC 1.4.1.2), and alkaline phosphatase (ËC 3.1.3.1) were determined in fully mechanized systems (Hitachi 737, Boehringer Mannheim, FRG and Cobas Bio centrifugal analyser, Hoffmann-LaRoche Grenzach, FRG) according to standard procedures (31). The activity of ornithine carbamyl transferase (ÉC 2.1.3.3) (32) was assayed manually using a reagent test kit from Bio Merieux, France.

\section{Statistical analyses}

The significance of differences was checked with the MannWhitney-Wilcoxon test; the statistical correlations were calculated with standard procedures (33).
Results

Effect of acute inflammation on toxic liver cell injury

Acute inflammation induced by subcutaneous injection of turpentine results after $48 \mathrm{~h}$ in severe dysproteinaemia (not shown), in an increase of plasma fibrinogen from $1.5 \pm 0.1 \mathrm{~g} / 1$ to $4.5 \pm 0.2 \mathrm{~g} / \mathrm{l}$, and in elevated functional concentrations ranging from 12.7 $\pm 0.9 \mathrm{kU} / 1$ (controls) to $22.5 \pm 3.5 \mathrm{kU} / \mathrm{l}(\mathrm{p}<0.005)$ of a protein determined with the chromogenic substrate assay for human $\alpha_{2}$-macroglobulin. The concentration of the protein measured with the corresponding assay for human $\alpha_{1}$-proteinase inhibitor remains unaffected (fig. 1). The turpentine-induced increase in the proteinase inhibitor in rat serum, designated here as $\alpha_{2}$-macroglobulin, is strongly reduced or absent in rats having either $D$-galactosamine- or thioacetamide-generated liver injury, which suggests that the inhibitor protein is synthesized in the liver. The view is supported by the decrease of $\alpha_{2}$-macroglobulin in serum of liver-injured rats (fig. 1).

The extent of biochemically monitored liver cell injury initiated by a single dose of $D$-galactosamine (fig. 2) and thioacetamide (fig. 3), respectively, is effectively diminished in rats with acute inflammation. Whereas both the cytosolic (alanine aminotransferase and aspartate aminotransferase) and the mitochondrial (glutamate dehydrogenase, ornithine carbomyltransferase, aspartate aminotransferase) liver cell enzymes exhibit significant $(p=0.005)$ elevations of their catalytic serum concentrations in toxic liver damages, the increase is only moderate in animals pretreated with turpentine when compared with control rats, and for each parameter it is significantly ( $p$ $=0.025$ ) smaller than in those rats without inflammation (fig. 2,3). Similar observations were made for alkaline phosphatase. The concentrations of total bile acids increase strongly and are more pronounced in the thioacetamide than in the $D$-galactosamine type of liver injury but remain almost unaffected in animals exposed to liver toxic agents in the presence of acute inflammation (fig. 2, 3).

When the extent of liver damage is related to the concentration of $\alpha_{2}$-macroglobulin in serum an inverse statistical correlation between the catalytic concentrations of hepatocellular enzymes and the functional concentrations of the proteinase inhibitor in rat serum becomes evident (fig. 4). The degree of negative correlation is obviously independent of the subcellular localization of the enzyme in the liver cell, i.e. it is similar for alanine aminotransferase and ornithine carbamyltransferase. 


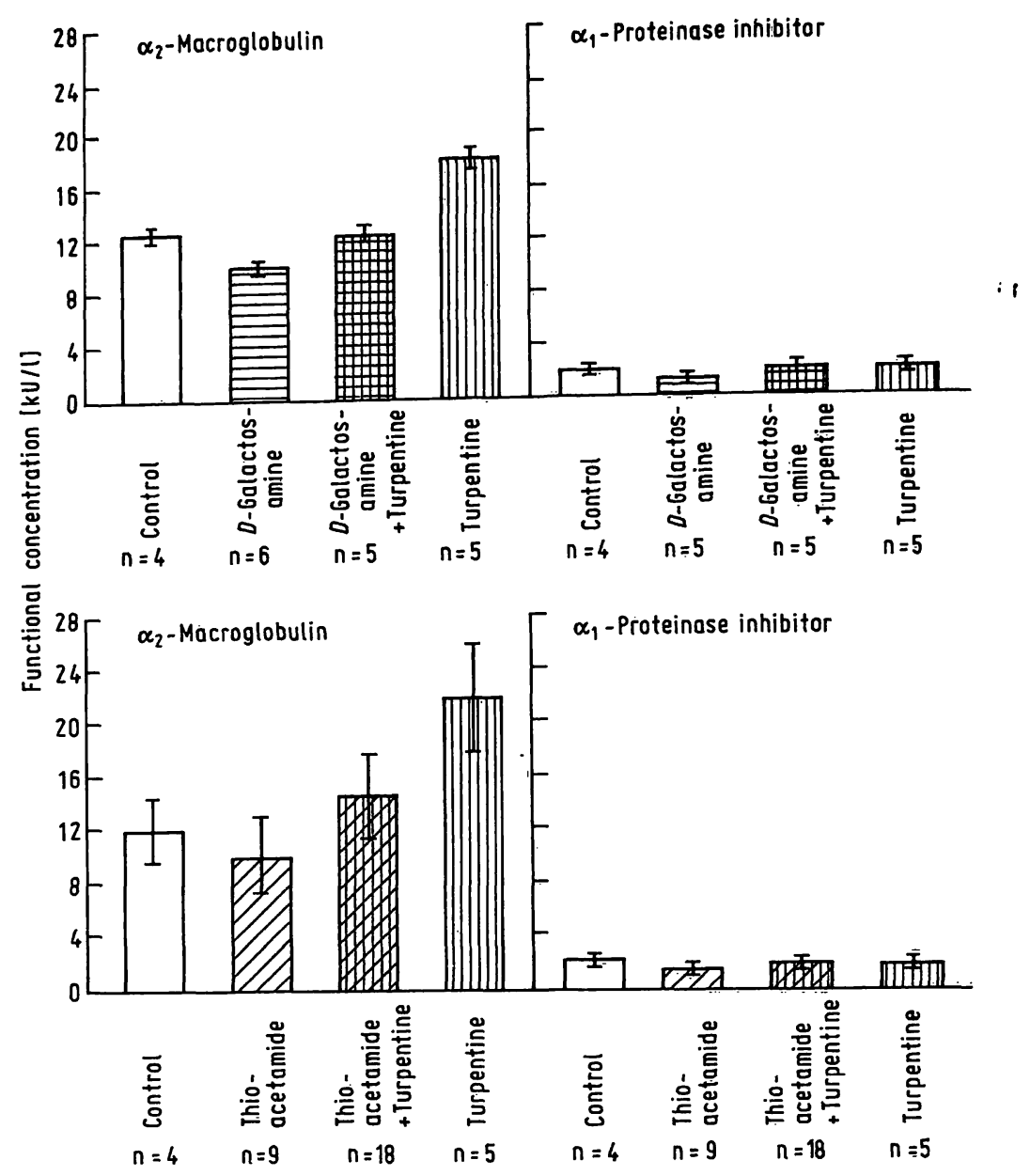

Fig. 1. Functional concentrations of proteins in rat serum determined with the chromogenic substrate assay for $\alpha_{2}$-macroglobulin and $\alpha_{1}$-proteinase inhibitor, respectively. The animals were sacrificed $24 \mathrm{~h}$ after Injection of $D$-galactosamine and thioacetamide and $48 \mathrm{~h}$ after application of turpentine. Rats receiving both turpentine and $D$-galactosamine or thioacetamide were injected with turpentine $24 \mathrm{~h}$ before application of the hepatotoxic agent. Control rats received saline. The mean concentrations $\pm S$. D. of $n$ independent experiments are given.

Changes of heparan sulphate synthesis in hepatocytes of rats with acute and subacute liver injury

Hepatocytes were isolated from rats injured for various times (up to 5 days) with a single dose of $D$ galactosamine $(500 \mathrm{mg} / \mathrm{kg}$ body weight). The cell incubation was extended up to $8 \mathrm{~h}$ during which time the vitality of the hepatocytes, as checked by trypan blue exclusion, decreased from an initial $90 \%$ to $85 \%$, the concentration of cell leakage enzymes in the medium increased less than $20 \%$ (lactate dehydrogenase, aspartate aminotransferase) or remained almost constant (alanine aminotransferase, glutamate dehydrogenase), and the incorporation of $\left.{ }^{35} \mathrm{~S}\right]$ sulphate into total glycosaminoglycans proceeded linearly (fig. 5). Twenty four hours after initiation of liver injury the synthesis of glycosaminoglycans is severely depressed, being (after a $8 \mathrm{~h}$ incubation period) less than 0.2 of that observed in the incubation of hepatocytes from control livers (fig. 5). Between $24 \mathrm{~h}$ and $48 \mathrm{~h}$, glycosaminoglycan synthesis recovers and is el- evated between $48 \mathrm{~h}$ and $120 \mathrm{~h}$ after initiation of liver damage. The maximal increase is reached after $96 \mathrm{~h}$, at which time hepatocytes from treated livers incorporate during a $8 \mathrm{~h}$ period about 1.5 times as much $\left[{ }^{35} \mathrm{~S}\right]$ sulphate into glycosaminoglycans as those from control livers. Slightly less stimulated glycosaminoglycan synthesis is observed between $48 \mathrm{~h}$ and $72 \mathrm{~h}$ (not shown) after induction of injury (fig. 5). The fraction of heparan sulphate synthesized in the hepatocytes was determined both at various times of incubation and in relation to the time after starting liver injury. Under all conditions heparan sulphate rep= resents between 0.85 and 0.92 of total $\left[{ }^{35}\right.$ S]labeled glycosaminoglycans; the appearance of enzymatically determined chondroitin sulphate and/or dermatan sulphate was not evident. This was also proven by nearly identical elution profiles of $\left.{ }^{35} \mathrm{~S}\right]$ labeled glycosaminoglycans from Dowex 1 X 2 (fig. 6) and DEAEsephacel anion exchanger. Thus, the time course given in figure 5 for total glycosaminoglycans is almost identical to that of heparan sulphate. 


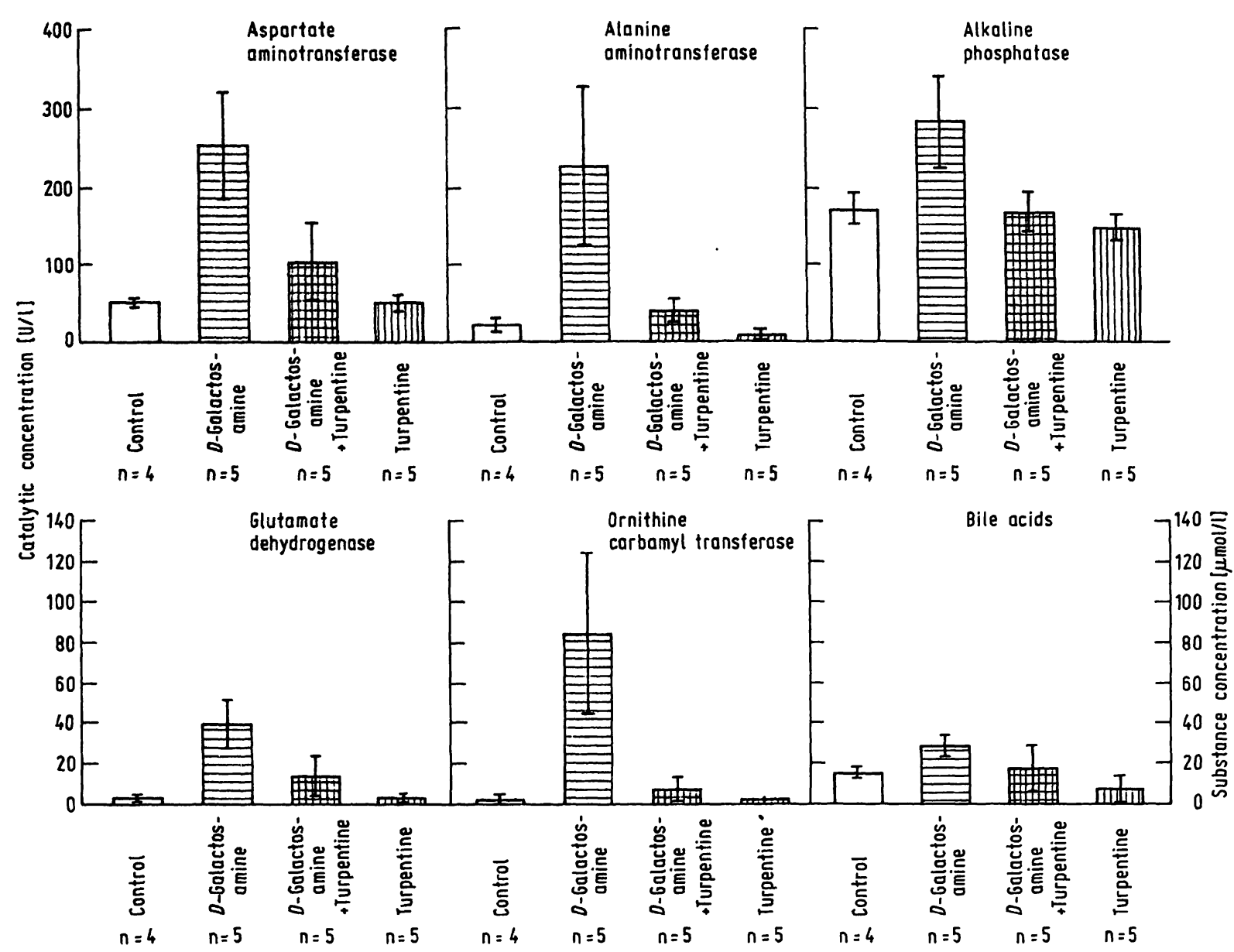

Fig. 2. Catalytic concentrations of aspartate aminotransferase, alanine aminotransferase, alkaline phosphatase, glutamate dehydrogenase, ornithine carbamyl transferase, and substance concentration of total bile acids in serum of rats treated with $D$-galactosamine, turpentine and with a combination of both. The time sequence of injections and sacrifice were as described in figure 1 . The mean concentrations $\pm S$. D. of $n$ independent experiments are shown.

Effect of acute inflammation on the inhibition of heparan sulphate synthesis in hepatocytes from rats with acute liver injury

The results presented above for $D$-galactosamineinduced liver injury hold also true for another model of toxic injury, i. e. thioacetamide-generated liver damage (fig. 7). Soon after application of the noxious agent the incorporation of $\left.{ }^{35} \mathrm{~S}\right] \mathrm{sulphate}$ into glycosaminoglycans is depressed (not shown); after $24 \mathrm{~h}$ the amount of $\left[{ }^{35}\right.$ S]labeled glycosaminoglycans synthesized during a $4 \mathrm{~h}$ incubation period is reduced by more than 0.60 when compared with hepatocytes from control rat livers. Interestingly, hepatocytes from rats with a normal liver but acute inflammation by turpentine, synthesized during the same period a nearly 1.8 fold elevated amount of $\left[{ }^{35} \mathrm{~S}\right]$ labeled glycosaminoglycans compared with control hepatocytes (fig. 7). Parenchymal cells from livers exposed to thioacetamide under acute inflammation reveal no decrease of glycosaminoglycan production. Instead, the incorporation of label is enhanced 3 fold and 1.3 fold compared with hepatocytes from thioacetamideinjured and control livers, respectively. Type-specific analysis of hepatocellular glycosaminoglycans by enzymatic and chemical means and by anion exchange chromatography reveals no changes of the profile of newly formed [ $\left.{ }^{35} \mathrm{~S}\right]$ labeled glycosaminoglycans. Under each condition the fraction of heparan sulphate varied between 0.85 and 0.90 , and galactosamine-containing glycosaminoglycans were not detected.

\section{Discussion}

Hepatocytoprotection is a promising field of research in experimental hepatology, because it provides results of immediate consequence for the treatment and prevention of human acute and chronic liver diseases (34). The chemical nature of the cytoprotective drugs is quite heterogeneous and ranges from eicosanoids and related factors $(35-40 \mathrm{a})$, synthetic terpenoid compounds (41), $\varepsilon$-aminocaproic acid (42), putre- 


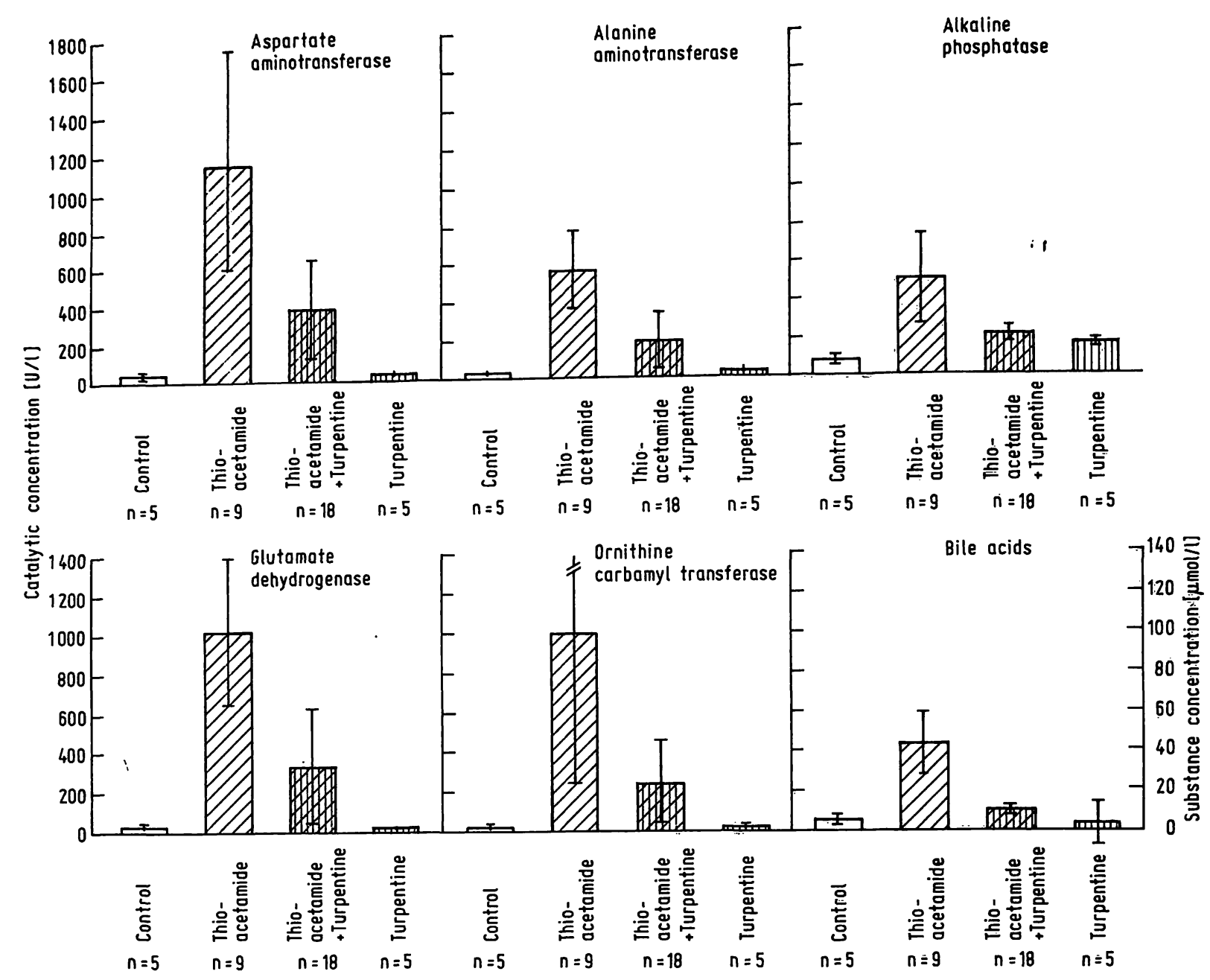

Fig. 3. Catalytic concentrations of aspartate aminotransferase, alanine aminotransferase, alkaline phosphatase, glutamate dehydrogenase, ornithine carbamyl transferase, and the concentration of total bile acids in serum of rats treated with thioacetamide, turpentine and with a combination of both. The time sequence of injections and sacrifice were as described in figure 1 . The mean concentrations $\pm S$. D. of $n$ independent experiments are given.

scine (42), cholestyramine (43), heptanone derivatives (44), and propylthiouracil (45) to some endogeneous, as yet poorly defined proteinaceous compounds in inflammatory exudates and sera $(21-23,46)$. The effect of these and other hepatocytoprotectants is mainly non-specific and, in most cases, not limited to a certain type of chemical liver cell necrosis. Their mechanism of action has been related to general as yet poorly defined "stabilizing functions" on inner and outer membrane structures $(38,41)$, to the inhibition of proteinases and esterases (46) known to be of pathogenetic significance (47) and to their functions as free radical scavengers, antioxidants and inhibitors of lipid peroxidation $(46,48)$.

The model of hepatoprotection applied here utilizes the beneficial effects on the liver of "counter irritation" $(21-23)$, i.e. the generation of factor(s) in serum or exudates by some unspecific irritants like turpentine, which are known to have anti-inflamma- tory potency $(49-53)$. In most cases these endogeneous anti-inflammatory factors are proteins, of which the synthesis in the liver is positively regulated in acute phase conditions (54). In fact, protection of the liver from the toxicity of $D$-galactosamine by competing unspecific injuries was ascribed to the excessive enhancement of the concentration of $\alpha_{2}$-macrofoetoprotein in serum (23). The acute phase protein was shown to have inflammation inhibiting properties in the carrageenin type and other models of non-specific inflammation $(49,50)$. Since turpentine injection resulted in only a moderate increase in the proteinase inhibitor (measured by its function with a chromogenic substrate developed for human $\alpha_{2}$-macroglobulin), this (these) protein(s) must be different from authentic rat $\alpha_{2}$-macroglobulin (55) and $\alpha_{2}$-macrofoetoprotein (23). The latter proteins, measured immunologically, rise several fold in serum during inflammation. However, as in the case of $\alpha_{2}$ macrofoetoprotein, we found an attenuation of liver 


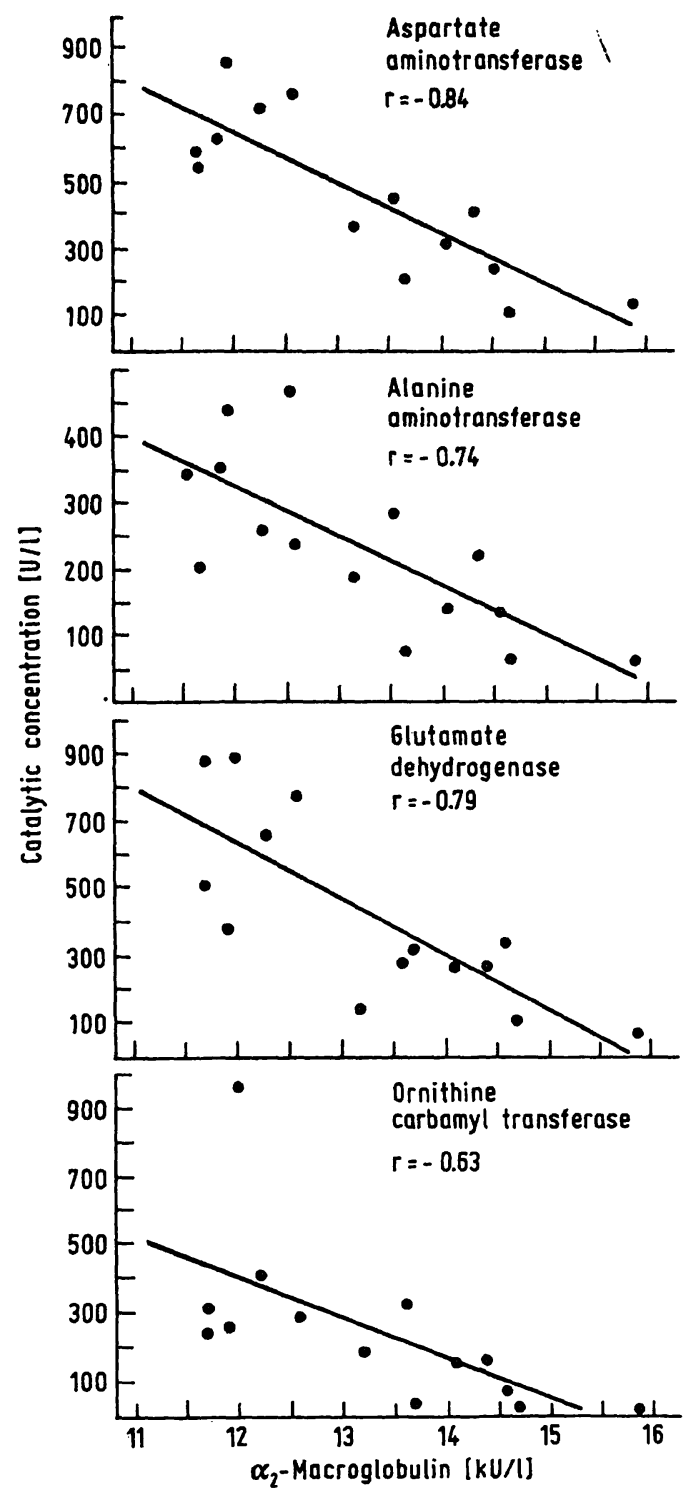

Fig. 4. Correlations between the catalytic concentrations of aspartate aminotransferase, alanine aminotransferase, glutamate dehydrogenase, and ornithine carbamyl transferase, respectively, and the functional concentration of the protein determined with the chromogenic substrate assay for human $\alpha_{2}$-macroglobulin in serum of rats treated with turpentine followed $24 \mathrm{~h}$ thereafter by an injection of $100 \mathrm{mg} / \mathrm{kg}$ body weight of thioacetamide. Animals were sacrificed $24 \mathrm{~h}$ after application of thioacetamide.

damage that correlated directly with the increase in the proteinase inhibitor. Futhermore, its increase following turpentine treatment was less in liver injured rats. The latter observation points to the liver as the source of the hepatoprotective agent. Thus, the injured liver will lose its ability of self protection against noxious agents, which forms a pathogenetic vicious circle, which results in an amplification of the hepatocellular toxicity of injurious drugs. Attempts to isolate the protective protein(s) from acute phase rat serum have been unsuccessful so far (56).

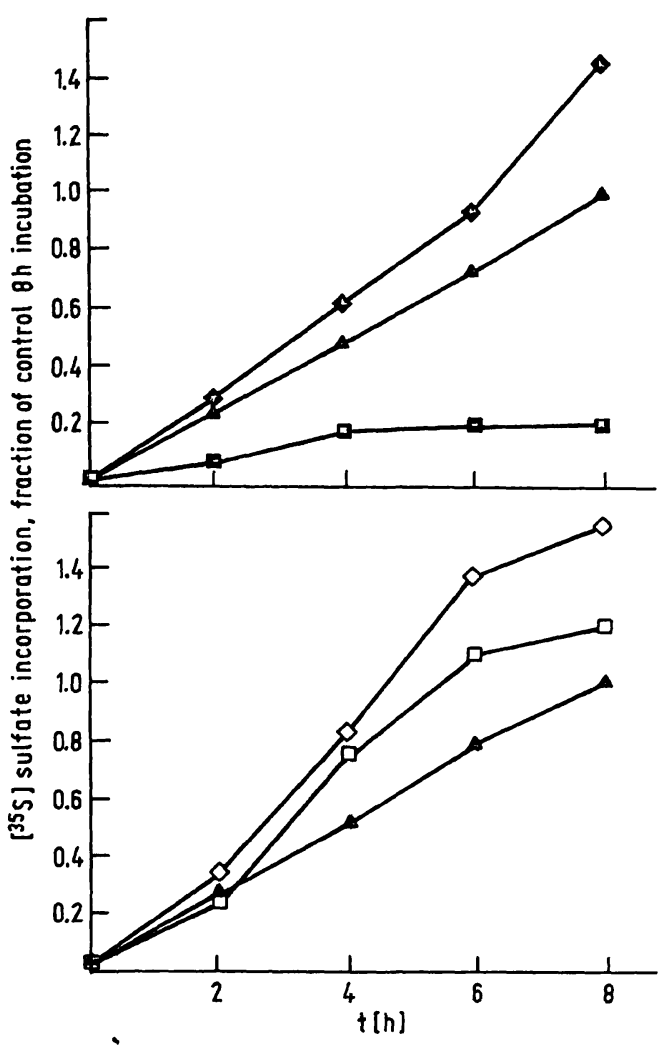

Fig. 5. Time courses of the incorporation of $\left.{ }^{35} \mathrm{~S}\right]$ sulphate into total glycosaminoglycans of hepatocytes isolated from rats injured for various times $24 \mathrm{~h}(\boldsymbol{D}-\square), 48 \mathrm{~h}(\bullet-\bullet)$, $96 \mathrm{~h}(\diamond-\diamond)$, and $120 \mathrm{~h}(\square-\square)$ with a single dose of 500 $\mathrm{mg} / \mathrm{kg}$ body weight of $D$-galactosamine. The results are expressed relatively as fractions of the amount of $\left[{ }^{35} S\right]$ sulphate incorporated by cells from normal liver during a $8 \mathrm{~h}$ period (about $1.6 \mathrm{kBq} / \mathrm{mg}$ DNA) ( $\Delta-$ $\Delta)$. A representative experiment out of three is shown (coefficient of variation about $20 \%$ ).

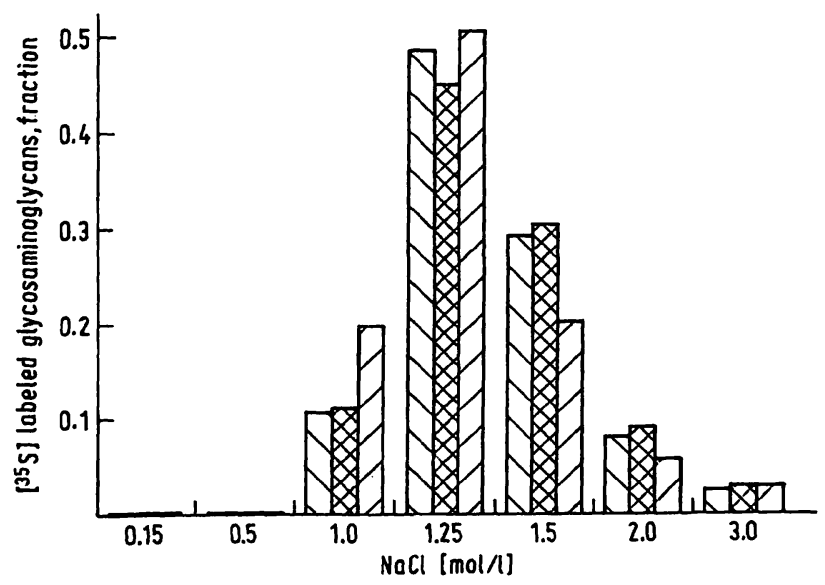

Fig. 6. Elution profile from Dowex $1 \times 2$ of $\left[{ }^{35}\right.$ S llabeled glycosaminoglycans synthesized by hepatocytes from control liver $($ ) and from livers damaged for $96 \mathrm{~h}(\mathbb{Q})$ and $120 \mathrm{~h}(\square)$ by a single dose of $D$-galactosamine. The elution was performed with a stepwise gradient of increasing $\mathrm{NaCl}$ concentrations, the radioactivity in the effluent is expressed as a fraction of total eluted [ $\left.{ }^{35} \mathrm{~S}\right] \mathrm{la}-$ beled glycosaminoglycan radioactivity. 


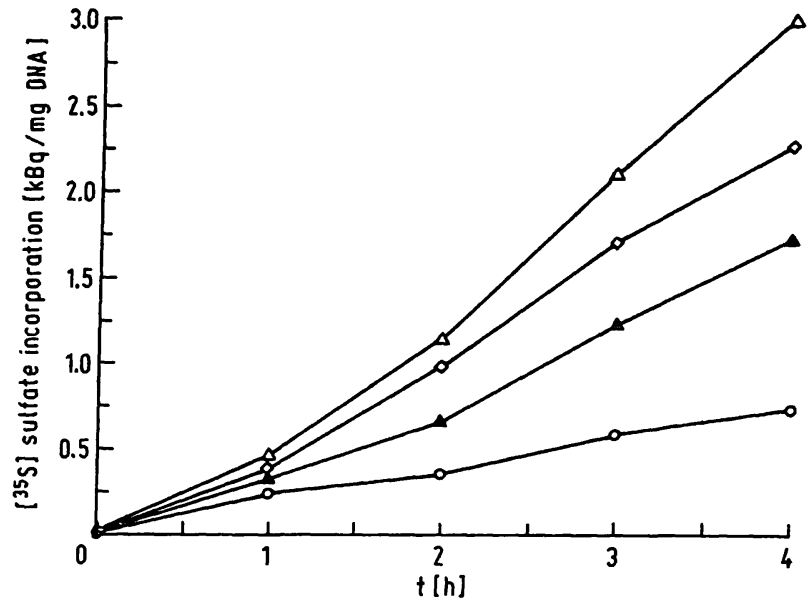

Fig. 7. Effect of turpentine-induced acute inflammation on the time course of the incorporation of $\left.{ }^{35} \mathrm{~S}\right]$ sulphate into total glycosaminoglycans of hepatocytes isolated from control rats (receiving saline) $(\Delta-\Delta)$, rats treated with turpentine $(\Delta-\Delta)$, with thioacetamide $(100 \mathrm{mg} / \mathrm{kg}$ body weight) $(0-0)$, and with a combination of turpentine and thioacetamide $(\diamond-\diamond)$. The time sequence of injections and death was as described in figure 1. A representative experiment out of three is documented (coefficient of variation is $20 \%$ )

Liver damage, irrespective of the mechanism of action of the various hepatotoxins, leads almost instantaneously after application of the drug to a severe depression of heparan sulphate synthesis in hepatocytes. The inhibition occurs much earlier than any other biochemical, morphological and clinical-chemical sign of liver cell injury. This is substantiated by previous results obtained with liver slices and livers in situ $(9-11)$ and demonstrated here for hepatocytes from livers exposed for $24 \mathrm{~h}$ to $D$-galactosamine or thioacetamide. Heparan sulphate synthesis was not inhibited in hepatocytes from livers exposed to either of these drug, if the rats were also subject to acute inflammation. The latter condition prevents the decrease of cell surface bound heparan sulphate shown previously to occur in early injured livers (8). This effect may hinder the deleterious dearrangement of intracellular $\mathrm{Ca}^{2+}$-homeostasis, which is thought to be of great significance for irreversible cell injury $(14-20)$. Elevated intracellular calcium activates phospholipases, which may further enhance the entry of calcium into hepatocytes by degradation of phospholipids of the plasma membrane (17). The maintenance of normal heparan sulphate synthesis in hepatocytes from livers exposed to $D$-galactosamine in the presence of acute inflammation is achieved although the primary biochemical lesion of $D$-galactosamine in the cell, i.e. depletion of UDP-glucose, UDPgalactose and other uracil nucleotides was reported to occur in protected livers (23). Therefore, synthesis of hepatocellular heparan sulphate obviously proceeds at a normal rate despite a depletion of UDPglucuronate, which was suggested to be the cause for the severe inhibition of hepatic heparan sulphate production induced by $D$-galactosamine (17). Our results also support the view that during the membrane-stabilizing effect of certain hepatoprotective factors generated in acute inflammatory conditions, the heparan sulphate composition of the cell coat is normal. Clearly, the possibility cannot be excluded that normal heparan sulphate synthesis in hepatocytes from livers exposed to noxious agents is the consequence rather than the cause of liver cell protection by acute inflammation. However, a depression of heparan sulphate synthesis in hepatocytes from drugexposed but protected livers, which was not observed in this study, would strictly argue against the hypothesis posed above (8). It should be noted here, but will be reported in detail elsewhere (57), that turpentine and other traumatic or inflammatory conditions stimulate significantly the synthesis of heparan sulphate in parenchymal liver cells. This type of glycosaminoglycan is identified as a novel, non-secreted and positively regulated acute phase reactant in rats. Future studies are concerned with the elucidation of the mechanism underlying the inflammatory response of hepatocellular heparan sulphate synthesis and the reversal of its depression in livers exposed to injurious chemicals. In this respect, the role of certain secretagogues of activated Kupffer cells (monokines) in the promotion of heparan sulphate synthesis in hepatocytes under these conditions deserves attention.

\section{References}

1. Stuhlsatz, H. W., Vierhaus, S., Gressner, A. M. \& Greiling, H. (1983) In: Structural Carbohydrates in the Liver (Popper, H., Reutter, W., Köttgen, E. \& Gudat, F., eds.) pp. 650-651, MTP Press Ltd., Lancaster.

2. Kojima, J., Nakamura, N., Kanatani, M. \& Obmori, K. (1975) Canc. Res. 35, 542-547. 3. Gressner, A. M. (1983) Hepato-Gastroenterology 30, 225-
229 .

4. Oldberg, A., Kjellen, L. \& Höök, M. (1979) J. Biol. Chem. $254,8505-8510$

5. Kjellen, L., Oldberg, A. \& Höök, M. (1980) J. Biol. Chem. 255, 10407-10413.

6. Kjellen, L., Pettersson, I. \& Höök, M. (1981) Proc. Natl. Acad. Sci. USA 78, $5371-5375$. 7. Riesenfeld, J. Höök, M. \& Lindahl, U. (1982) J. Biol.
Chem: 257, 7050-7055. 
8. Gressner, A. M. \& Vascl, A. (1984) In: Mechanisms of Hepatocyte Injury and Death (Keppler, D., Popper, H., Bianchi, L. \& Reutter, W., eds.) pp. 129-138, MTP Press Ltd., Lancaster.

9. Gressner, A. M. \& Köster-Eiserfunke (1981) J. Clin. Chem. Clin. Biochem. 19, 363-370.

10. Gressner, A. M., Pazen, H. \& Greiling, H. (1977) HoppeSeylers Z. Physiol. Chem. 358, 825-833.

11. Gressner, A. M., Heinrigs, S. \& Grouls, P. (1982) J. Clin. Chem. Clin. Biochem. 20, 15-24.

12. Mattai, J. \& Kwak, J. C. T. (1981) Biochim. Biophys. Acta $677,303-312$.

13. Vannucchi, S., Del Rosso, M., Gella, C., Urbano, P. \& Chiarugi, V. (1978) Biochem. J. 170, 185-187.

14. Farber, J. L. (1982) Lab. Invest. 47, 114-123.

15. Schanne, F. A. X., Pfau, R. G. \& Farber, J. L. (1980) Am. J. Pathol. 100, 25-38.

16. Farber, J. L., Chien, K. R. \& Mittnacht, S. (1981) Am. J. Pathol. 102, $271-281$.

17. Schiessel, C., Forsthove, C. \& Keppler, D. (1984) Hepatology 4, 855-861.

18. Fritz, M. M. \& Keppler, D. O. R. (1982) Naturwissenschaften 69, 147-148.

19. Farber, J. L. (1982) In: Progress in Liver Diseases (Popper, H. \& Schaffner, F., eds.) pp. 347-360, Vol. VIl, Grune \& Stratton, New York, London.

20. Kane, A. B., Young, E. E., Schanne, F. A. X. \& Farber, J. L. (1980) Proc. Natl. Acad. Sci. USA 77, 1177-1180.

21. Laden, C., Quentin Blackwell, R. \& Fosdick, L. S. (1958) Am. J. Physiol. 195, 712-718.

22. Lewis, D. A. (1977) Biochem. Pharmacol. 26, 693-698.

23. Gool, v. J., Boers, W. \& De Nie, I. (1978) Exp. Mol. Pathol. $29,228-240$.

24. Gressner, A. M: \& Vasel, A. (1985) Mech. Age. Dev. 31, $307-327$.

25. Seglen, P. O. (1976) In: Methods in Cell Biology, pp. 2983, Vol. XIII, Academic Press, New York.

26. Gressner, A. M. \& Grouls, P. (1982) Digestion 23, 259264.

27. Gressner, A. M. \& Peltzer, B. (1984) J. Clin. Chem. Clin. Biochem. 22, 633-640.

28. Zerbe, O. \& Gressner, A. M. (1985) Lab. Med. 9, 186.

29. Mashige, F., Tanaka, N., Maki, A., Kamei, S. \& Yamanaka, M. (1981) Clin. Chem. 27, $1352-1356$.

30. Labarca, C. \& Paigen, K. (1980) Anal. Biochem. 102, $344-$ 352.

31. Bergmeyer et al. (1972) Z. Klin. Chem. Klin. Biochem. 10, $281-291$.

32. Frederiks, W. M., Vogels, I. M. C. \& Fronik, G. M. (1984) Cell Biochem. Funct. 2, 217-220.

33. Sachs, L. (1984) Angewandte Statistik: Anwendung statistischer Methoden, 6. Auflage, Springer-Verlag, Berlin.

34. Burk, R. F. (1981) Gastroenterology 81, 397-398.
35. Stachura, J., Tarnawski, A., Szczudrawa, J., Bogdal, J., Mach, T., Klimczyk, B. \& Kirchmayer, S. (1980) Folia Histochem. Cytochem. 18, 311-318.

36. Ujhelyi, E., Divald, A., Vajta, G., Jeney, A. \& Lapis, K. (1984) Acta Physiol. Hungarica 64, 425-430.

37. Divald, A., Ujhelyi, E., Jeney, A., Lapis, K. \& Institoris, L. (1985) Exp. Mol. Pathol. 42, 163-166.

38. Stachura, J., Tarnawski, A., Ivey, K. J., Mach, T., Bogdal, J., Szczudrawa, J. \& Klimczyk, B. (1981) Gastroenterology $81,211-217$.

39. Robert, A. (1979) Gastroenterology 77, 761-767.

40. Ruwart, M. J., Rush, B. D., Friedle, N. M., Stachura, J. \& Tarnawski, A. (1984) Hepatology 4, 658-660.

40a. Noda, Y., Hughes, R. D. \& Williams, R. (1986) J. Hepatology 2, 53-64.

41. Fujiwara, K., Ohta, Y., Ogata, I., Sato, Y., Oka, Y., Hayashi, S., Takatsuki, K. \& Oka, H. (1984) Hepatology 4, 1134-1136.

42. Putnam, C. W., Buckley, A. R., Warneke, J. A., Karrer, F. M., Rhenman, B. \& Steinbronn, K. (1984) Surgery 96, 214-222.

43. Bioulac, P., Despuyoos, L., Bedin, C., Iron, A., Saric, J. \& Balabaud, C. (1981) Gastroenterology 81, 520-526.

44. Ferreyra, de E. C., Fenos, de O. M. \& Castro, J. A. (1984) Res. Commun. Chem. Pathol. Pharmacol. 46, 289-292.

45. Yamada, T., Ludwig, S., Kuhlenkamp, J. \& Kaplowitz, N. (1981) J. Clin. Invest. 67, 688-695.

46. Lewis, D. A. (1984) Biochem. Pharmacol. 33, 1705-1714.

47. Tanner, A., Keyhani, A., Reiner, R., Holdstock, G. \& Wright, R. (1981) Gastoenterology 80, 647-654.

48. Par, A: \& Javor, T. (1984) Acta Physiol. Hungarica 64, 409-423.

49. Ufkes, J. G. R., Zeegers, A., Boers, W. \& Gool, v. J. (1983) Arch. Internat. Pharmacodynamie et Therapie 262, 287298.

50. Gool, v. J., Ladiges, N. C. J. J., Nie, de I. \& Boers, W. (1977) In: Agents and Actions (Bonta, I. L., ed.) Suppl. 2, pp. 150-161 Birkhäuser Verlag, Basel.

51. Billingham, M. E. J., Robinson, B. V. \& Robson, J. M. (1969) Br. Med. J. 2, 93-96.

52. DiPasquale, G., Girerd, R. J., Beach, V. L. \& Steinetz, B. G. (1963) Am. J. Physiol. 205, 1080-1082.

53. Boers, W., Gool, v. J. \& Zwart, N. A. (1979) Br. J. Exp. Pathol. 60, 239-245.

54. Billingham, M. E. J., Gordon, A. H. \& Robinson, B. V. (1971) Nature New Biol. 231, 26-27.

55. Bauer, J., Birmelin, M., Northoff, G.-H., Northemann, W., Tran-Thi, T.-A., Ueberberg, H., Decker, K. \& Heinrich, P. C. (1984) Febs Lett. 177, 89-94.

56. Kirch, Ch., Lahme, B. \& Gressner, A. M. (1985) J. Clin. Chem. Clin. Biochem. 23, 571.

57. Gressner, A. M. \& Djovkar, A. (1986) Inflammation, in press.
Prof. Dr. A. M. Gressner

Abteilung für Klinische Chemie

und Zentrallaboratorium der Universität

Baldingerstraße

D-3550 Marburg 
